\title{
SUPERVISI MANAJERIAL KEPALA MADRASAH DALAM MENINGKATKAN KEDISIPLINAN KERJA GURU MADRASAH
}

\section{Candra Wijaya}

Universitas Islam Negeri Sumatera Utara Medan

Jl. William Iskandar Ps. V, Medan Estate, Kec. Percut Sei Tuan, Kabupaten Deli

Serdang, Sumatera Utara 20371

Email: shohibulmumtaz@gmail.com

\begin{abstract}
ABSTRAK
Tujuan penelitian ini adalah untuk mengetahui: 1) Pelaksanaan supervisi manajerial di Madrasah Aliyah Swasta Pondok Pesantren Mawaridussalam Batang Kuis; 2) Realitas disiplin kerja guru madrasah; 3) Faktor pendorong dan penghambat disiplin kerja guru madrasah; dan 4) Kontribusi supervisi manajerial dalam meningkatkan disiplin kerja guru madrasah. Penelitian menggunakan pendekatan kualitatif dengan metode deskriptif. Hasil penelitian ini adalah 1) Pelaksanaan supervisi manajerial dilaksanakan oleh kepala madrasah dengan mendelegasikan tugas sepervisi kepada para wakil kepala madrasah sesuai dengan bidang masing-masing. 2) Realitas kedisiplinan guru Madrasah cukup baik 3) Faktor pendukung peningkatan disiplin guru Madrasah bermula dari keikhlasan kerja guru dan motivasi dari atasan berupa aturan yang harus ditaati oleh guru. Sementara faktor penghambatnya lebih disebabkan adanya sebagian guru yang mengajar di madrasah ini juga kuliah ditempat yang lain sehingga kadang ditemukan keterlambatan yang masih dalam batas ditoleransi; dan 4) Kontribusi supervisi manajerial dapat meningkatkan kedisiplinan para guru. Kedisiplinan tersebut ditunjukkan dengan kinerja guru yang melaksanakan tugas dan tanggung jawabnya secara baik dan benar serta memiliki dedikasi pengabdian yang tinggi untuk mewujudkan tujuan madrasah.
\end{abstract}

Kata Kunci: Implementasi, Supervisi Manajerial, Kedisiplinan

\section{ABSTRACT}

The purpose of this study was to determine: 1) Implementation of managerial supervision in Madrasah Aliyah Private Boarding School Mawaridussalam Batang Quiz; 2) The reality of madrasa teacher work discipline; 3) Factors driving and inhibiting the work discipline of madrasah teachers; and 4) Contribution of managerial supervision in improving the work discipline of madrasah teachers. The study uses a qualitative approach with descriptive methods. The results of this study are: 1) The implementation of managerial supervision is carried out by the headmaster of the madrasah by delegating supervisory duties to the deputies of the headmaster in accordance with their respective fields. 2) The reality of Madrasa teacher discipline is quite 
good 3) The supporting factor of increasing Madrasa teacher discipline starts from the sincerity of the teacher's work and motivation from the superiors in the form of rules that must be obeyed by the teacher. While the inhibiting factor is due more to the fact that there are some teachers who teach in this madrasa also study at other places so that sometimes it is found that delays are still within tolerable limits; and 4) The contribution of managerial supervision can improve the discipline of teachers. This discipline is shown by the performance of teachers who carry out their duties and responsibilities properly and correctly and have a high dedication of dedication to realizing the goals of madrasas.

Keywords: Implementation, Managerial Supervision, Discipline

\section{PENDAHULUAN}

Efektifitas pendidikan dapat diketahui dari efektivitas pengajaran yang dilakukan oleh guru. Karena melalaui peran seorang guru arah pembelajaran siswa akan semakin jelas, termasuk strategi pembelajaran dalam menyampaikan materi pelajaran agar terjadi perubahan perilaku siswa (kognitif, afektif dan psikomotorik). Untuk itu secara manajerial kepala sekolah perlu upaya memastikan pelaksanaan pembelajaran dengan cermat dan terarah sesuai realitas pembelajaran yang dilaksanakan oleh guru, sehingga pengawasan atau supervisi pembelajaran menjadi kegiatan yang penting sekali untuk menjamin ketercapaian tujuan melalui pembelajaran yang kondusif.

Guru pada idealnya harus dijadikan idola dan dihormati oleh peserta didik, maka guru harus mampu memanfaatkan setiap kesempatan untuk menunjukkan perilaku yang baik, berdisiplin dan menanamkan nilai-nilai moral yang sangat penting bagi perkembangan kejiwaan siswanya. Perilaku guru akan memberikan warna dan corak tersendiri terhadap watak peserta didik di kemudian hari. Contoh teladan yang ditunjukkan oleh guru akan lebih mudah melekat dalam perilaku siswa dibandingkan dengan pembelajaran secara verbal.

Sutrisno (2014) menjelaskan disiplin merupakan alat yang digunakan para manajer untuk berkomunikasi dengan karyawan agar mereka bersedia untuk mengubah suatu prilaku serta usaha untuk mereka meningkatkan kesadaran dalam menaati peraturan perusahaan dan norma-norma sosial yang berlaku. Oleh karena itu guru yang disiplin secara otomatis terbentuk apabila guru senantiasa berpedoman dan memulai dari hal-hal yang kecil terlebih dahulu kemudian menjadi kebiasaan dan akhirnya terinternalisasi pada diri seorang guru.

Menurut Singodimedjo dikutip dari Sutrisno (2014), faktor yang mempengaruhi kedisiplinan seorang karyawan adalah besar kecilnya kompensasi, ada tidaknya keteladanan pemimpin dalam organisasi, ada tidaknya aturan pasti yang menjadi pegangan, keberanian pimpinan dalam mengambil tindakan, ada tidaknya pengawasan pimpinan, ada tidaknya perhatian pada karyawan, dan diciptakan kebiasaan-kebiasaan yang mendukung tegaknya disiplin. Hal tersebut akan berjalan dengan baik apabila masing-masing guru mempunyai self management seperti yang dijelaskan Reinecke (2016) bahwa guru dan tenaga kependidikan lainnya harus mempunyai management self dalam menjalankan tugasnya di lembaga 
pendidikan agar segala peraturan yang telah disepakati dengan pihak sekolah tidak mudah dilanggar atau ditinggalkan dengan sengaja.

Istilah supervisi sudah lama dikenal dalam pendidikan. Supervisi sering diidentikkan dengan pengawasan. Syafaruddin (2014) menjelaskan Secara etimologis istilah supervisi atau dalam bahasa inggris disebut dengan supervision sering didefinisikan sebagai pengawasan. Secara morfologis, supervisi terdiri dari dua kata yaitu super yang berarti atas atau lebih dan visi mempunyai arti lihat, pandang, tilik atau awasi. Supervisi atau pengawasan merupakan salah satu bagian aktivitas pendidikan yang dimaksudkan untuk memberikan arah atau bantuan agar proses pembelajaran yang berlangsung di suatu organisasi atau lembaga pendidikan berkualitas. Kualitas tersebut memerlukan dukungan kepemimpinan kepala sekolah, guru yang mengajar, pegawai tata usaha yang menjalankan tugas administrasi, siswa yang belajar, maupun komponen lain yang ikut serta mendukung terlaksananya pembelajaran pada lembaga pendidikan.

Supervisi identik dengan pengawasan. Terry (2006) mengartikan pengawasan sebagai mendeterminasi apa yang telah dilaksanakan, maksudnya mengevaluasi prestasi kerja dan apabila perlu, menerapkan tindakan-tindakan korektif sehingga hasil pekerjaan sesuai dengan rencana yang telah ditetapkan. Kimball Wiles yang dikutip oleh Sutisna (1989) menjelaskan supervisi sebagai "bantuan dalam pengembangan situasi mengajar-belajar yang lebih baik". Hal tersebut merupakan "suatu kegiatan supervisi pelayanan yang disediakan untuk membantu para guru menjalankan pekerjaan mereka dengan lebih baik". Peranan supervisor ialah "membantu, mendukung, dan membagi, bukan menyuruh". Wiles menyatakan bahwa supervisi yang baik hendaknya mengembangkan kepemimpinan di dalam kelompok, membangun program latihan dalam jabatan untuk meningkatkan keterampilan guru, dan membantu guru meningkatkan kemampuan dalam menilai hasil pekerjaannya.

Secara spesifik supervisi yang ditujukan bagi peningkatan mutu madrasah dari segi pengelolaan disebut dengan supervise manajerial. Aedi (2014:16) menyatakan bahwa supervise administrasi atau manajerial menitik beratkan pada pengamatan supervisor pada aspek-aspek administrasi yang berfungsi sebagai pendukung (supporting) dan pelancar terlaksananya pembelajaran. Kualitas madrasah yang baik muncul karena adanya pengelolaan yang baik dari pihak madrasah dan juga tidak lupa peran dari seorang pengawas. Dengan demikian, peran pengawas madrasah sangat mendukung dari kemajuan madrasah karena tanpa adanya pengawas yang ahli (professional) maka tidak mungkin juga sebuah madrasah akan berjalan baik dan bermutu (Y. Meriza, 2015: 526).

Fungsi dan tujuan supervisi, kedua hal ini cukup sulit untuk dibedakan sebab seringkali suatu objek dapat diterangkan dari segi fungsi dan dapat pula dari segi tujuan. Menurut Made Pidarta17 bahwa fungsi supervisi bertalian dengan badan atau organisasi secara keseluruhan. Sedangkan tujuan supervisi adalah bertalian dengan kegunaan, yaitu digunakan untuk apa.

Berdasarkan uraian di atas, supervisi bermaksud untuk membantu para guru menjadi terarah dalam kegiatan pembelajarannya, dan menjadikan seorang guru tersebut untuk lebih memperhatikan tanggung jawabnya sebagai 
seorang guru serta dengan adanya supervisi ini guru mampu memberi pertangggungjawaban atas apa yang diperbuatnya dan diharapkan menajadi lebih baik lagi.

Pekerjaan kepala sekolah yang paling rumit dan berat adalah manajemen. Manajemen akan terjadi manakala ada kekacauan, kesulitan, atau gejolak yang menimpa sekolah. Kekacauan itu bisa berasal dari dalam sekolah sendiri dan dapat juga dari luar sekolah. Kekacauan itu bisa berasal dari dalam antara lain adalah akibat terjadinya kepentingan antar kelompok informal. Sedangkan kekacauan dari luar bisa disebabkan karena tidak puasnya sejumlah orang tua siswa akan hasil ujian nasional, dengan memberi cap kepada sekolah sebagai sekolah yang tidak berbobot.

Menghadapi gejolak-gejolak tersebut, kepala sekolah dalam menyelesaikan tugas ini menduduki posisi manajer yang mengatur manajemen. Dalam menyelesaikan masalah-masalah rumit tersebut, menurut Pidarta (2009) manajer mempunyai empat fungsi serta dilengkapi dengan tiga keterampilan manajer. Keempat fungsi manajer atau manajemen itu adalah: 1) Perencanaan, yaitu merencanakan tindakan untuk mengatasi masalah tersebut. 2) Pengorganisasian, yaitu mengorganisasikan orang dan perlengkapan lainnya agar hasil perencanaan dapat berjalan. 3) Penggerakkan, ialah menggerakkan dan memotivasi para personilia agar bekerja dengan giat dan antusias. 4) Pengendalian, ialah mengendalikan proses kerja dan hasil kerja agar tidak menyimpang dari rencana semula dan kalau menyimpang segera dapat diperbaiki.

Kepala sekolah melakukan supervisi atau pengawasan terhadap segala bentuk aktivitas yang berlangsung dalam proses pembelajaran, termasuk didalamnya melakukan supervisi atau pengawasan terhadap orang perorang yang menjadi bagian dari proses pembelajaran tersebut, serta melakukan supervisi atau pengawasan terhadap perangkat-perangkat pembelajaran dan administrasi pembelajaran, terutama terhadap guru.

Di samping itu, kepala sekolah merupakan manajer yang mengarahkan dan melakukan langkah-langkah strategis dalam usaha menjalankan roda organisasi sekolah agar berjalan efektif dan mencapai target yang diinginkan. Karena itu, kepala sekolah membuat terobosan-terobosan dengan mengarahkan semua komponen sekolah yang terlibat dengan menyusun kerangka kerja dan membuat target-target yang akan dicapai dalam beberapa waktu dimasa depan. Kemudian dibuat juga rencana strategis sekolah mulai dari rencana jangka pendek, menengah, dan panjang.

Pengawasan disini adalah pengawasan yang bertujuan untuk meningkatkan kinerja para pendidik dan pegawai sekolah lainnya dengan cara memberikan pengarahan-pengarahan yang baik dan bimbingan serta masukan tentang cara atau metode mendidik yang baik dan profesional. Dalam perkembangannya, supervisi lebih menekankan kepada persahabatan yang dilandasi oleh pemberian pelayanan dan kerjasama yang lebih baik dan bersifat demokratis. Dalam perkembangannya, supervisi pendidikan memberikan pengaruh yagn baik pada perkembangan pendidikan di Indonesia, sehingga para pendidik memiliki kemampuan mendidik yang kreatif. Aktif, efektif dan inovatif. 
Mulyasa (2007) menjelaskan guru sebagai pendidik adalah yang menjadi tokoh, panutan, dan identifikasi bagi para pesera didik, dan lingkungannya. Oleh karena itu, guru harus memiliki standar kualitas pribadi tertentu, yang mencakup tanggung jawab, wibawa, mandiri dan disiplin. Berkenaan dengan disiplin guru dimaksudkan harus mematuhi berbagai peraturan dan tata tertib secara konsisten, atas kesadaran profesional, karena mereka bertugas untuk mendisiplinkan para peserta didik disekolah, terutama dalam pembelajaran. Oleh karena itu dalam menanamkan disiplin guru harus memulai dari dirinya, dalam berbagai tindakan dan prilakunya.

Peneliti melihat hal itu ada di Madrasah Aliyah Swasta Pondok Pesantren Mawaridussalam Batang Kuis dan sehubungan dengan itu peneliti merasa tertarik mengkaji lebih mendalam tentang "Supervisi Manajerial dalam Meningkatkan Kedisiplinan Kerja Guru di Madrasah Aliyah Swasta Pondok Pesantren Mawaridussalam Batang Kuis".

\section{METODE}

Penelitian ini dilaksanakan dengan menggunakan pendekatan kualitatif dengan fenomenologi, hal itu didasarkan pada maksud untuk mendeskripsikan perilaku informan yaitu Kepala sekolah maupun guru Madrasah Aliyah Swasta Pondok Pesantren Mawaridussalam Batang Kuis sesuai situasi sosial yang ada. Menurut Bogdan dan Taylor dalam Moleong (1989) bahwa penelitian kualitatif menghasilkan deskripsi/uraian berupa kata-kata tertulis atau lisan dari perilaku para aktor yang dapat diamati dalam suatu situasi sosial. Dalam konteks ini peneliti berusaha memahami implementasi supervisi manajerial dalam meningkatkan disiplin kerja guru di Madrasah Aliyah Swasta Pondok Pesantren Mawaridussalam Batang Kuis. Dalam menafsirkan data atas makna perilaku informan maka digunakan penafsiran fenomenologik dengan pola maksud, tujuan dan pemaknaan.

Huberman dan Miles (1994) menerangkan bahwa dalam penelitian kualitatif analisis data secara umum dibagi menjadi tiga tingkat; analisis pada tingkat awal, analisis pada saat pengumpulan data lapangan, dan analisis setelah selesai pengumpulan data. Maka dalam penelitiannya, peneliti melakukan analisis data sejak awal pengumpulan data sampai selesai. Adapun proses analisis data pada saat pengumpulan data terdiri dari: 1) kegiatan dimulai dari proses penelusuran data dengan teknik observasi, wawancara dan studi dokumentasi, 2) data atau informasi yang diperoleh diidentifikasi satuan analisisnya dan alternatif kategori yang mungkin untuk satuan analisis itu, dan 3) satuan analisis atau alternatif kategori itu diuji keabsahannya melalui triangulasi, memperhatikan kemungkinan adanya kasus negatif dan kasus ekstrim. Apabila data yang diperoleh sudah dianggap jenuh, selanjutnya data didokumentasikan ke dalam kartu-kartu kode satuan analisis atau kartu kategori. Semua kegiatan ini dilakukan secara terstruktur dan terdokumentasi.

Analisis data tahap pengumpulan data dilakukan dengan cara mencatat data hasil wawancara, hasil observasi, dan studi dokumentasi pada buku atau lembaran catatan lapangan. Kemudian peneliti mengelompokkan, menggolongkan data/informasi yang diperoleh dalam satu fokus tertentu sesuai jumlah fokus penelitian. Data dari kepala madrasah maupun guru, serta pihak- 
pihak lain yang dianggap dapat memberikan jawaban atas masalah penelitian dihubungkan dan diuraikan sehingga benar-benar tidak ada lagi variasi data.

Untuk memperkuat kesahihan data hasil temuan dan keotentikan penelitian, maka peneliti mengacu kepada penggunaan standar keabsahan data yang disarankan oleh Lincoln dan Guba (1985), yang terdiri dari credibility, transferability, dependability dan conformability.

Credibility merupakan kegiatan membuat lebih terpercaya atau credible proses, interpretasi dan temuan dalam penelitian ini yaitu dengan cara: (a) keterikatan yang lama dengan yang diteliti dalam berhubungan dengan implmentasi supervisi manajerial dalam meningkatkan disiplin kerja guru di Madrasah Swasta Pondok Pesantren Mawaridussalam Batang Kuis, dilaksanakan dengan tidak tergesa-gesa sehingga pengumpulan data dan informasi tentang situasi sosial dan fokus penelitian akan diperoleh secara sempurna, (b) ketekunan pengamatan terhadap manajemen peningkatan mutu kinerja pengawas madrasah untuk memperoleh informasi yang sahih, (c) melakukan triangulasi atau triangulation, yaitu informasi yang diperoleh dari beberapa sumber diperiksa silang antara data wawancara dari kepala madrasah maupun guru, serta pihak-pihak lain yang dianggap dapat memberikan jawaban atas masalah penelitian, kemudian data wawancara dengan data pengamatan dan dokumen.

Keteralihan sebagai persoalan empiris bergantung pada kesamaan antara konteks pengirim dan penerima. Untuk melakukan pengalihan tersebut seorang peneliti mencari dan menggumpulkan kejadian empiris tentang kesamaan konteks. Dengan demikian peneliti bertanggung jawab untuk menyediakan data deskriptif secukupnya jika ia ingin membuat keputusan tentang pengalihan tersebut. Untuk keperluan itu peneliti harus melakukan penelitian kecil untuk memastiksn usaha verifikasi tersebut.

Dependability merupakan konsep kebergantungan lebih luas dari pada realibilitas. Hal tersebut disebabkan peninjauan yang dari segi bahwa konsep itu diperthitungkan segala-galanya yaitu yang ada pada realibilitas itu sendiri ditambah faktor-faktor lainya yang tersangkut.

Peneliti mengusahakan konsistensi dalam keseluruhan proses penelitian ini agar dapat memenuhi persyaratan yang berlaku. Semua aktivitas penelitian harus ditinjau ulang terhadap data yang telah diperoleh dengan memperhatikan konsistensi dan dapat dipertanggungjawabkan baik itu dokumen, hasil wawancara maupun hasil observasi yang telah dilaksanakan sebelumnya.

Dapat dikonfirmasikan atau confirmability dilakukan untuk menjaga objektivitas-subjektivitasnya sesuatu hal bergantung pada orang seorang, menurut Scriven (1974). Selain itu masih ada unsur kualitas yang melekat pada konsep objektivitas. Hal itu digali dari pengertian bahwa jika sesuatu itu objek, berarti dapat dipercaya, faktual, dan dapat dipastikan. Subjektif berarti tidak dapat dipercaya, atau menceng. Pengertian terakhir inilah yang dijadikan tumpuan pengalihan pengertian objektivitas-subjektivitas menjadi kepastian.

Data harus dapat dipastikan keterpercayaannya atau diakui oleh banyak orang (objektivitas) sehingga kualitas data dapat dipertanggung jawabkan sesuai spektrum, fokus dan latar alamiah penelitian yang dilakukan. Oleh karena itu selama proses pengumpulan data hingga laporan penelitian ini harus jelas sumber yang digunakan. 
HASIL DAN PEMBAHASAN

\section{Pelaksanaan supervisi manajerial di Madrasah Aliyah Swasta Pondok Pesantren Mawaridussalam Batang Kuis}

Supervisi manajerial dilaksanakan oleh kepala madrasah dengan mendelegasikan bidang yang mesti disupervisi kepada para wakil kepala madrasah sesuai dengan bidang yang ada. Kegiatan supervisi ini dimaksudkan sebagai kegiatan pemantauan dan pembinaan terhadap pengelolaan dan administrasi madrasah, dimana fokus supervisi ini ditujukan pada pelaksanaan bidang garapan manajemen madrasah, yang antara lain meliputi: 1) manajemen kurikulum dan pembelajaran, 2) kesiswaan, 3) sarana dan prasarana, 4) ketenagaan, 5) keuangan, 6) hubungan sekolah dengan masyarakat, dan 7) layanan khusus.

Sudrajat (2009) menjelaskan bahwa dalam melaksanakan tugas supervise manajerial, sejatinya pengawas maupun kepala madrasah berperan sebagai kolaborator dan negosiator dalam proses perencanaan, koordinasi, dan pengembangan manajemen sekolah. Asesor dalam mengidentifikasi kelemahan dan menganalisis potensi sekolah, dan pusat informasi pengembangan mutu sekolah. Evaluator terhadap pemaknaan hasil pengawasan.

Pada hakikatnya supervisi mengandung beberapa kegiatan pokok, yaitu pembinaan yang kontinyu, pengembangan kemampuan profesional personel, perbaikan situasi belajar mengajar, dengan sasaran akhir pencapaian tujuan pendidikan dan pertumbuhan pribadi peserta didik. Dengan kata lain, dalam supervisi ada proses pelayanan untuk membantu atau membina guru-guru. Pembinaan ini menyebabkan perbaikan atau peningkatan kemampuan profesional guru, kemudian selanjutnya ditransfer ke dalam perilaku mengajar sehingga terciptanya situasi belajar mengajar yang lebih efektif dan pada akhirnya dapat meningkatkan prestasi belajar peserta didik. Jadi pengertian supervisi lebih difokuskan kepada upaya memberi layanan dan bantuan, baik secara individual maupun secara kelompok dalam usaha memperbaiki pengajaran, sehingga guru dan tenaga kependidikan lainnya merasakan bimbingan dari seorang supervisor, bukan sebagai hubungan antara atasan dengan bawahan tetapi suatu hubungan kemanusiaan (M. S. Nugraha, 2015; 45).

Supervisi manajerial menerapkan beberapa prinsip yang mestinya dipedomani, diantaranya adalah sebagai berikut: 1) pengawas maupun kepala madrasah harus menjauhkan diri dari sifat otoriter, di mana ia bertindak sebagai atasan dan kepala sekolah/guru sebagai bawahan; 2) supervisi harus mampu menciptakan hubungan kemanusiaan yang harmonis. Hubungan kemanusiaan yang harus diciptakan harus bersifat terbuka, kesetiakawanan, dan informal; 3) supervisi harus dilakukan secara berkesinambungan. Supervisi bukan tugas bersifat sambilan yang hanya dilakukan sewaktu-waktu jika ada kesempatan; 4) supervisi harus demokratis. Supervisor tidak boleh mendominasi pelaksanaan supervisi. Titik tekan supervisi yang demokratis adalah aktif dan kooperatif; 5) Program supervisi harus integral. Di dalam setiap organisasi pendidikan terdapat bermacam-macam sistem perilaku dengan tujuan sama, yaitu tujuan pendidikan; 6) supervisi harus komprehensif. Program supervise harus mencakup keseluruhan aspek, karena hakikatnya suatu aspek 
pasti terkait dengan aspek lainnya; 7) supervisi harus konstruktif. Supervisi bukanlah sekali-kali untuk mencari kesalahan-kesalahan guru; 8) supervisi harus obyektif dalam menyusun, melaksanakan, dan mengevaluasi, keberhasilan program supervisi harus obyektif. Obyektivitas dalam penyusunan program berarti bahwa program supervisi itu harus disusun berdasarkan persoalan dan kebutuhan nyata yang dihadapi sekolah.

\section{Realitas disiplin kerja guru madrasah Aliyah Swasta Pondok Pesantren Mawaridussalam Batang Kuis}

Kedisiplinan guru Madrasah Alaiyah Swasta Pondok Pesantren Mawaridussalam Batang Kuis menunjukkan tingkat yang baik dimana jika dipersenkan tingkat kedisiplinan yang ditunjukkan guru dalam bekerja mencapai $90 \%$. Seperti yang dijelaskan Moekijat (1983) bahwa kata disiplin berasal dari kata Latin yaitu: disciplina yang berarti latihan atau pendidikan kesopanan dan kerohanian serta pengembangan tabiat. Sedangkan Sutrisno (2014) berpendapat bahwa disiplin adalah sikap hormat terhadap peraturan dan ketetapan perusahaan, yang ada dalam diri karyawan, yang menyebabkan ia dapat menyesesuaikan diri dengan sukarela pada peraturan dan ketetapan perusahaan. Disiplin adalah kesediaan dan kerelaan seseorang untuk mematuhi dan mentaati segala norma peraturan yang berlaku di organisasi. Tanpa kedisiplinan seseorang yang baik sulit bagi organisasi termasuk sekolah mencapai hasil yang optimal.

Warnich, Carrell, Elbert, dan Hatfield (1995) menyebutkan bahwa disiplin merupakan bagian yang menjiwai keseluruhan fungsi-fungsi manajemen untuk meningkatkan kinerja setiap individu dan organisasi. Kegiatan tanpa disiplin tidak akan menghasilkan manfaat. Pandangan yang berbeda dikemukakan oleh Dessler (2009) bahwa disiplin dimaknai sebagai latihan atau pendidikan kesopanan dan kerohanian serta pengembangan tabiat. Untuk mendorong karyawan berperilaku hati-hati dengan cara taat pada aturan dan keputusan. Latihan atau pendidikan ini merupakan salah satu dasar bagi para anggota suatu organisasi atau kelompok untuk dapat mewujudkan semua tujuannya. Hal ini karena disiplin mengacu pada ketertiban dan keteraturan. Sementara Darmodihardjo dalam Sinaga (2010) berpendapat bahwa disiplin kerja adalah sikap mental yang mengandung kerelaan hati yang nampak dari tingkah laku untuk memenuhi semua ketentuan, peraturan dan norma yang berlaku dalam menunaikan tugas dan tanggung jawab dalam suatu organisasi.

Disiplin menurut Suseno (2009) adalah kegiatan manajemen untuk menjalankan standar-standar organisasi. Dengan demikian berarti tujuan yang telah ditentukan dan disepakati oleh para anggota organisasi itu akan dapat dicapai secara sadar mau menghormati dan menegakkan setiap aturan dan ketentuan-ketentuan yang berlaku dilingkungan organisasi tersebut. Kesadaran untuk menegakkan peraturan itu merupakan asas fundamental bagi para anggota organisasi dalam setiap kegiatan dengan peran, tugas dan kewajibannya masing-masing. Tanpa ada ketertiban dan peraturan dalam bekerja, organisasi akan menghadapi berbagai kesulitan dalam usaha menuju tercapainya tujuan yang telah disepakati. Kedisiplinan dalam bekerja juga diperuntukkan untuk memotivasi para anggota organisasi agar tunduk dan patuh pada aturan yang telah ditetapkan. Dengan demikian, disiplin berfungsi 
juga sebagai penyelenggaraan administrasi. Disiplin terdapat pada bagian penyelenggaraan administrasi dalam organisasi yang terdapat lingkup kerja administrasi personil.

Guru yang memiliki kedisiplinan yang tinggi pada gilirannya akan mendorong peningkatan kinerjanya. Soetjipto (2008) menerangkan kinerja merupakan suatu istilah secara umum yang digunakan untuk sebagian atau seluruh tindakan atau aktivitas dari suatu organisasi pada suatu periode dengan referensi pada sejumlah standar seperti biaya-biaya masa lalu atau yang diproyeksikan, dengan dasar efisiensi. Kinerja dalam hal ini merupakan tanda keberhasilan organisasi dan orang-orang yang termasuk didalam organisasi tersebut. Menurut Hitt, Ireland dan Hoskisson, (2001) adapun orang - orang yang berkepentingan dengan organisasi adalah pekerja, baik manajerial maupun non manajerial. Untuk itu kinerja perlu dilakukan secara kolaboratif dan kooperatif dengan cara menggunakan manajemen kinerja, dimana hal tersebut merupakan suatu cara mencegah kinerja yang buruk dan mampu menerapkan cara bekerja sama untuk meningkatkan kinerja. Selain itu, manajer perlu memperhatikan kinerja atasannya karena manajer tersebut sebagian bertanggung jawab kepada atasannya.

\section{Faktor pendorong dan penghambat disiplin kerja guru madrasah Aliyah Swasta Pondok Pesantren Mawaridussalam Batang Kuis}

Faktor pendukung peningkatan disiplin guru di Madrasah Aliyah Swasta Pondok Pesantren Mawaridussalam Batang Kuis bermula dari diri sendiri, keikhlasan dan juga motivasi dari atasan berupa aturan yang harus ditaati oleh guru. Para guru juga menyadari bahwa mereka seorang figur yang dicontoh oleh peserta didik, untuk itu agar siswa memiliki kedisiplinan maka itu harus bermula dari guru itu sendiri. Sementara faktor penghambatnya lebih disebabkan adanya sebagian guru yang mengajar di madrasah ini juga kuliah ditempat yang lain sehingga kadang ditemukan keterlambatan mereka untuk masuk kelas, namun masih dalam batas ditoleransi.

Disiplin yang dikembangkan atau dikontrol oleh diri sendiri. Hal ini merupakan manifestasi atau aktualisasi dari tanggung jawab pribadi yang berarti mengakui dan menerima nilai-nilai yang ada di luar dirinya. Melalui disiplin diri guru merasa bertanggung jawab dan dapat mengatur dirinya sendiri untuk kepentingan organisasi. Penanaman nilai-nilai disiplin dapat berkembang apabila didukung oleh situasi lingkungan yang kondusif yaitu situasi yang diwarnai perlakuan yang konsisten dari guru dan pimpinan. Disiplin diri sangat besar peranannya dalam mencapai tujuan organisasi. Melalui disiplin diri seorang guru selain menghargai dirinya sendiri juga menghargai orang lain. Misalnya jika guru mengerjakan tugas dan wewenang tanpa pengawasan atasan, pada dasarnya guru telah sadar melaksanakan tanggung jawab yang telah dipikulnya. Hal itu berarti guru mampu melaksanakan tugasnya. Pada dasarnya ia menghargai potensi dan kemampuannya. Di sisi lain, bagi rekan sejawat, dengan diterapkan disiplin diri akan memperlancar kegiatan yang bersifat kelompok, apalagi jika tugas kelompok tersebut terkait dalam dimensi waktu, dimana suatu proses kerja yang dipengaruhi urutan waktu pengerjaannya. Ketidakdisiplinan dalam suatu bidang kerja akan menghambat bidang kerja lain. 


\section{Kontribusi supervisi manajerial dalam meningkatkan disiplin kerja guru madrasah Aliyah Swasta Pondok Pesantren Mawaridussalam Batang Kuis}

Disiplin kerja guru sangatlah penting dalam sebuah madrasah untuk mempengaruhi perkembangan peserta didik yang bertujuan untuk memberikan motivasi secara langsung untuk peserta didik dan memberikan contoh tauladan secara langusung kepadanya. Dengan demikian untuk meningkatkan kediplinan guru itu sendiri kepala sekolah diharapkan mampu mengimplementasikan supervisi manajerial ini secara tegas dan tepat. Dengan adanya supervisi manajerial ini diharapkan mampu meningkatkan kedisiplinan para guru serta mendorong mereka untuk melaksanakan tugas dan tanggung jawabnya secara baik dan benar serta memiliki dedikasi pengabdian yang tinggi untuk mewujudkan tujuan pondok pesantren maupun madrasah. Hasibuan (2005) mengemukan bahwa disiplin yang baik mencerminkan besarnya tanggung jawab seseorang terhadap tugas-tugas yang diberikan kepadanya. Karena hal ini akan mendorong gairah atau semangat kerja, dan mendorong terwujudnya tujuan organisasi.

Semangat atau moril adalah suatu istilah yang banyak dipergunakan tanpa adanya suatu perumusan yang seksama. Semangat menggambarkan suatu perasaan, agak berhubungan dengan tabiat (jiwa), semangat kelompok, kegembiraan atau kegiatan. Untuk kelompok pekerja, penggunaan yang sudah lazim menyatakan bahwab semangat menunjukkan iklim dan suasana pekerjaan. Guru dengan semangat yang tinggi merasa bahwa mereka diikutsertakan tujuan organisasi patut diberi perhatian dan bahwa usaha-usaha mereka dikenal dan dihargai. Guru dengan semangat yang tinggi memberikan sikap yang positif, seperti kesetiaan, kegembiraan, kerjasama, kebanggaan dalam bekerja dan ketaatan kepada kewajiban. Produktivitas dan efisiensi yang tinggi cenderung merupakan akibat sikap-sikap dan tindakan-tindakan demikian. Sikap dan tindakan itu diantaranya disiplin. Disiplin termasuk dalam sikap mental guru. Yang dimaksud dalam sikap mental adalah sikap terhadap kerja itu sendiri, terhadap bekerja dalam industri, terhadap perlunya menghasilkan produk bermutu, terhadap pelayanan prima kepada stakeholders dan akhirnya terhadap integritas moral dan reputasi. Kedisiplinan harus ditegakkan dalam suatu madrasah karena tanpa dukungan disiplin guru yang baik, maka madrasah akan sulit dalam mewujudkan tujuanya. Jadi dapatlah dikatakan bahwa kedisplinan merupakan kunci keberhasilan suatu madrasah dalam mencapai tujuan yang telah ditentukan.

\section{SIMPULAN}

Penelitian ini menyimpulkan bahwa supervisi manajerial dilaksanakan oleh kepala madrasah dengan mendelegasikan kepada para wakil kepala madrasah. Kegiatan supervisi tersebut dilaskanakan melalui pemantauan dan pembinaan pengelolaan dan administrasi madrasah meliputi: (a) manajemen kurikulum dan pembelajaran, (b) kesiswaan, (c) sarana dan prasarana, (d) ketenagaan, (e) keuangan, (f) hubungan sekolah dengan masyarakat, dan (g) layanan khusus. Kedisiplinan guru Madrasah Aliyah Swasta Pondok Pesantren Mawaridussalam Batang Kuis sudah bagus mencapai 90\%. Faktor pendukung peningkatan disiplin guru di Madrasah Aliyah Swasta Pondok Pesantren Mawaridussalam Batang Kuis bermula dari diri sendiri, keikhlasan, dan juga 
motivasi atasan berupa aturan yang harus ditaati oleh guru. Sementara faktor penghambat lebih disebabkan adanya sebagian guru yang mengajar di madrasah kuliah ditempat yang lain sehingga kadang ditemukan keterlambatan mereka untuk masuk kelas. Implementasi supervisi manajerial berkontribusi meningkatkan kedisiplinan para guru serta mendorong mereka untuk melaksanakan tugas dan tanggung jawabnya secara baik dan benar serta memiliki dedikasi pengabdian yang tinggi untuk mewujudkan tujuan pondok pesantren maupun madrasah.

\section{REFERENSI}

Dessler, G. (2009). Human Resource Management. Jakarta: Indeks.

Hitt, M. A., Ireland, R. D., \& Hoskisson, R. E. (2001). Strategic Management. Jakarta: Salemba Empat.

Huberman, A. M., \& Milles, M. B. (1994). Data Management and Analysis Methods. New Delhi: Sage Publication.

Lincoln, Y. S., \& Guba, E. G. (1985). Naturalistic Inquiry. California: Sage.

Moekijat. (1983). Manajemen Kepegawaian Personal Management. Bandung: Offset Alumni.

Moleong, L. J. (1989). Metodologi Penelitian Kualitatif. Bandung: Remaja Rosdakarya.

Mulyasa. (2007). Standart Kompetensi dan Sertifikasi Guru. Bandung: Remaja Rosdakarya.

Meriza, Y. (2015). Supervisi Manajerial Pengawas Madrasah Aliyah. Jurnal Manajer Pendidikan. Vol. 9 No. 4 https://ejournal.unib.ac.id/index.php/ manajerpendidikan/article/view/1155.

Nugraha, M. S., (2015). Jurnal Nadwa. Vol. 9 No.1. (http://www.journal.walisongo.ac.id/index.php/Nadwa/article/view/520

Pidarta, M. (2009). Supervisi Pendidikan Kontekstual. Jakarta: Rineka Cipta.

Reinecke, D. R. (2016). Self Management For Building Independence : Research and Future Directions. United States: Long Island University Post.

Scriven, M. S. (1974). Evaluation Perspective and Procedures in W. James Popham Ed., Evaluation in Education: Current Applications. Berkeley: Mc Cutchan Puolishing Company.

Sinaga, Anton, "Hubungan Antara Disiplin Kerja dan Iklim Organisasi Dengan Kinerja Guru Di SMP Negeri Kelurahan Raya Kabupaten Simalungun". Tesis tidak diterbitkan. Medan: Program Pascasarjana UNIMED Medan, 2010.

Soetjipto, B. W. (2008). Paradigma Baru Manajemen Sumer Daya Manusia. Yogyakarya: Amara Book.

Sudrajat, A. (2009). Dimensi Kompetensi Supervisi Manajerial. Jakarta: Musyawarah Kerja Pengawas.

Susesno, D. B. (2009). Leader Yang Ship. Jakarta: Milestone.

Sutisna, O. (1989). Administrasi Pendidikan. Bandung: Angkasa.

Sutrisno, E. (2014). Manajemen Sumber Daya Manusia. Jakarta: Kencana.

Syafaruddin. (2014). Manajemen Kepengawasan Pendidikan. Bandung: Cita Pustaka.

Terry, G. R. (2006). Prinsip-Prinsip Manajemen. Jakarta: Bumi Aksara. 
Candra Wijaya

Warnich, S., Carrel, M. R., Elbert, N. F., \& Hatfiled, R. D. (1995). Human Resources Management. New Jersey: Prentice Hall Inc. 